\title{
Comparison of 1-and 2- Minute Sitting Position Versus Immediately Lying Down of Hemodynamic Variables after Spinal Anesthesia with Hyperbaric Bupivacaine in Elective Cesarean Section
}

By

\author{
Dr. Ahmed Salam Dawood ${ }^{* 1}$; Assist.Prof. Dr. Aimen Hameed Latef ${ }^{* 2}$ \\ ${ }^{* 1}$ M.B.Ch.B./FICMS A\&IC/Al Shaheed Dr.Fairuz Hospital/Wasit Health Directory/ Ministry \\ of Health and Environment, Iraq; ${ }^{* 2}$ M.B.Ch.B./DA/FICMS A\&IC/Consultant Anesthetist
}

\section{Abstract:}

the aim of current study: was Comparison of 1-and 2- minute sitting position versus immediately lying down on hemodynamic variables after spinal anesthesia with hyperbaric bupivacaine in elective cesarean section. Patients and methods: This study was performed after the approval of the Iraqi Council for Medical Specialization in anesthesia and intensive care, and after obtaining the consents from 90 pregnant women (at term) who were candidate for cesarean section with spinal anesthesia were recruited in this study. They were collected from "AL-Imamain AL-Kademain Medical City Teaching Hospital" (July 2017 - January 2018) , All patients were premedicated with 10mg IV metoclopramide and 50mg IV ranitidine, Base line blood pressure and the pulse rate were recorded initially before intervention, the Lumbar puncture was performed in the sitting position under full aseptic teqnique, For assessment of blood pressure and pulse rate, ten readings were taken at $(3,5,10,15,20,25$, 30, 35,40and $60 \mathrm{~min}$ ) using an automated noninvasive blood pressure. Pulse rate monitored by electrocardiogram and oximetry (SPO2). Results: Current study showed higher means of pulse rate than the other two groups especially at early times after anesthesia induction. On the other hand, both group A1 and A2 showed higher mean of systolic, diastolic and mean blood pressure than group B especially 3, 5, 10 and 15 minutes after anesthesia induction, so the variation of pulse rate over the time in the three groups. Group B had higher pulse rate 
than the other two groups at 3,5,10, 25 and 40 minutes with significant difference $(\mathrm{P}<0.05)$, while variation in systolic pressure in the three group over time. During the first 15 minutes after anesthesia induction group A2 showed significantly higher systolic pressure than both A1 and B groups as well as Variations in diastolic pressure between the three groups over time is shown in table 4. Both group A1 and A2 exhibited higher diastolic pressure than group B during the first 15 minutes, also Variation of mean blood pressures over time after the induction of anesthesia ,so During the first 20 minutes after anesthesia induction, 18 women (60\%) experienced hypotension compared to 11(36.67\%) in group A1 and only 6 (20\%) in group A2 and during the time period between 20 and 40 minutes, the three group exhibited close numbers of cases that had hypotension, Mean ephedrine requirements in direct lying, after 1 minute lying and after 2 minutes lying was $14.8 \pm 4.5 \mathrm{mg}, 13.4 \pm 3.9 \mathrm{mg}$ and $9.3 \pm 3.8 \mathrm{mg}$ respectively, the time required to reach T6 dermatome sensory level in the three groups. Group A2 exhibited longer time period to reach this level $(4.73 \pm 1.69$ min), Apgar score $>8$ in all groups. Conclusions: This study revealed that the patient's position is an important factor, which affects the frequency of Hypotension and the onset of sensory block, as well as Administration of spinal anesthesia for cesarean section. Based on the findings, keeping the parturient seated for 1 Or 2 minutes after spinal anesthesia, compared to immediately lying down, could decrease the frequency of hypotension.

keywords: Comparison; 1-and 2- Minute; Sitting Position; Lying Down; Hemodynamic Variables; Spinal Anesthesia; Hyperbaric Bupivacaine; Elective Cesarean Section 


\section{Introduction}

A Caesarean section is a surgical procedure in which one or more incisions are made through a mother's abdomen (laparotomy) and uterus (hysterotomy) to deliver one or more babies. The first modern Caesarean section was performed by German gynecologist Ferdinand Adolf Kehrer in 1881. ${ }^{(1,2,3)}$

Spinal anesthesia, also called spinal analgesia (because it can be used as A Post lower limb operations analgesia), spinal block or sub-arachnoid block $(\mathrm{SAB})$, is a form of regional anesthesia involving injection of a local anesthetic into the subarachnoid space, generally via a fine needle through intervertebral foramen (L4 -L5) or (L3-L4) ${ }^{(1)}$. Spinal anesthesia is often selected for elective or emergency cesarean section. ${ }^{(4,5)}$

Bupivacaine is a local anesthetic drug belonging to the amino amide group. It is commonly marketed under various trade names, including Marcaine (Astra Zeneca UK), Marcaine (Care stream Dental, Hospital Inc.), Sensor Caine (Astra Zeneca), and 'Vivacaine (Septodont). It is on the WHO Model List of Essential Medicines, the most important medication needed in a basic health system $^{(1)}$.

Bupivacaine binds to the intracellular portion of voltage-gated sodium channels and blocks sodium influx into nerve cells, which prevents depolarization. Hence, it blocks the generation and the conduction of nerve Impulses ${ }^{(1)}$.

\section{Aim of the study}

Comparison of 1-and 2- minute sitting position versus immediately lying down on hemodynamic variables after spinal anesthesia with hyperbaric bupivacaine in elective cesarean section. 


\section{patients and methods:}

This study was performed after the approval of the Iraqi Council for Medical Specialization in anesthesia and intensive care, and after obtaining the consents from the patients.

In a randomized clinical trial, 90 pregnant women (at term) who were candidate for cesarean section with spinal anesthesia were recruited in this study. They were collected from "AL-Imamain AL-Kademain Medical City Teaching Hospital" (July 2017 - January 2018).

The inclusion criteria were Elective C.S under spinal anesthesia; Class II of ASA ad Single fetus so the exclusion criteria were Patient refusal; Cerebral vascular disease; Fetal abnormality; History of allergy to drugs used; Contraindications to spinal anesthesia; History of diabetes mellitus, cardiac and renal diseases, hypertension and Obese patient.

In this study 90 patients that were scheduled for elective cesarean section by spinal anesthesia. Patients were divided into three groups: Group A1 (30 pt) had spinal anesthesia and lied down after one minute of sitting so the Group A2 (30pt) had spinal anesthesia and lied down after two minutes of sitting and Group B (30pt) served as control which had spinal anesthesia and were lied down immediately.

\section{Procedures}

From each patient, full history was taken and weight, height and age were recorded, All patients were premedicated with $10 \mathrm{mg}$ IV metoclopramide and 50mg IV ranitidine, Base line blood pressure and the pulse rate were recorded initially before intervention, the Lumbar puncture was performed in the sitting position under full aseptic teqnique, For assessment of blood pressure and pulse rate, ten readings were taken at $(3,5,10,15,20,25,30,35,40$ and $60 \mathrm{~min})$ using an automated noninvasive blood pressure. Pulse rate monitored by 
electrocardiogram and oximetry (SPO2) so , I.V. access was established and 1L of normal saline $(0.9 \%)$ was administered as preload fluid, as well as A 25 gauge (Pencil point, Braun, Germany) spinal needle was introduced into the subarachnoid space at the L3-L4 lumber level midline approach with the needle orifice cephalic,After free flow of cerebrospinal fluid out of the needle, hyperbaric bupivacaine was injected to subarachnoid space of the three Groups.The spinal needle was withdrawn and patients were positioned supine immediately in group B and after 1 minute in group A1 and after 2 minutes in A2.

All patients were placed supine with left uterine displacement. Oxygen 4$5 \mathrm{~L} /$ min given using a clear facemask. Onset of spinal anesthesia was confirmed by asking the patient about numbness of the legs. Surgery was started when the sensory level of the block reached T4 maternal blood pressure (BP), peripheral oxygen saturation (SPO2).Pulse rate, nausea, vomiting and fetal Apgar score were recorded.

\section{Statistical Analysis}

Data were organized in Microsoft Office Excel software and analyzed with statistical package for social sciences (SPSS) version 20. Numerous data were expressed as mean \pm standard deviation unless otherwise specified. Repeated measures analysis of variance (ANOVA) was used to analyze pulse rate SBP, DBP and mean BP over time. Bonferr's post-hoc was used for comparison between groups. Fisher's exact chi-square test was used to analyze categorical variables. A p-value of less than 0.05 was considered significant.

\section{Results}

A total of 90 parturient women were divided randomly into three equal groups. Table 1 shows the baseline characteristics of the three groups involved in this study. Although, group A2 exhibited higher mean of age, and lower 
mean of ephedrine use and gestational age, none of the listed factor showed significant difference between these groups except ephedrine use.

Table 1: Demographic and anesthetic baseline data of the study population

\begin{tabular}{|l|l|l|l|l|}
\hline \multicolumn{1}{|c|}{ Variables } & \multicolumn{1}{|c|}{$\begin{array}{c}\text { Direct lying } \\
\text { (30 cases) }\end{array}$} & $\begin{array}{c}\text { After } \mathbf{1} \\
\text { minute } \\
\mathbf{3 0} \text { cases })\end{array}$ & $\begin{array}{c}\text { After } \text { 2 minutes } \\
\text { (30 cases) }\end{array}$ & $\begin{array}{c}\text { P- } \\
\text { value }\end{array}$ \\
\hline Age, years & $31.2 \pm 5.3$ & $29.9 \pm 6.1$ & $32.1 \pm 6.9$ & 0.265 \\
\hline Weight, $\mathrm{kg}$ & $83.4 \pm 9.2$ & $86.6 \pm 9.5$ & $87.3 \pm 8.6$ & 0.504 \\
\hline Height, cm & $163.9 \pm 18.4$ & $158.7 \pm 17.9$ & $161.4 \pm 15.8$ & 0.774 \\
\hline Gestational age, $\mathrm{w}$ & $38.6 \pm 2.9$ & $38.3 \pm 4.1$ & $38.1 \pm 2.6$ & 0.651 \\
\hline
\end{tabular}

$\mathrm{Kg}$ : kilogram, cm: centimeter, w: week, mg: milligram

Generally, group B showed higher means of pulse rate than the other two groups especially at early times after anesthesia induction. On the other hand, both group A1 and A2 showed higher mean of systolic, diastolic and mean blood pressure than group B especially 3, 5, 10 and 15 minutes after anesthesia induction

Table 2 shows the variation of pulse rate over the time in the three groups. Group B had higher pulse rate than the other two groups at 3,5,10, 25 and 40 minutes with significant difference $(\mathrm{P}<0.05)$, while there were no significant differences between group A1 and A2.

Table 2: pulse rate for the three groups over time after the induction of anesthesia

\begin{tabular}{|l|l|l|l|l|l|l|}
\hline \multirow{2}{*}{ Time } & \multicolumn{3}{|l|}{ Pulse rate } & P-value \\
\cline { 2 - 7 } & $\begin{array}{l}\text { Group } \\
\text { (B) }\end{array}$ & $\begin{array}{l}\text { Group } \\
\text { (A1) }\end{array}$ & $\begin{array}{l}\text { Group } \\
\text { (A2) }\end{array}$ & P1 & P2 & P3 \\
\hline Baseline & 88.61 & 89.18 & 92.11 & 0.809 & 0.783 & 0.884 \\
\hline 3 min & 101.43 & 92.46 & 94.26 & 0.028 & 0.022 & 0.435 \\
\hline 5 min & 98.2 & 91.57 & 90.1 & 0.035 & 0.033 & 0.904 \\
\hline 10 min & 93.76 & 89.09 & 88.14 & 0.041 & 0.044 & 0.897 \\
\hline
\end{tabular}




\begin{tabular}{|l|l|l|l|l|l|l|}
\hline $15 \mathrm{~min}$ & 90.64 & 89.22 & 86.59 & 0.623 & 0.087 & 0.145 \\
\hline $20 \mathrm{~min}$ & 89.18 & 87.54 & 84.49 & 0.719 & 0.614 & 0.743 \\
\hline $25 \mathrm{~min}$ & 89.67 & 85.17 & 84.12 & 0.042 & 0.047 & 0.693 \\
\hline $30 \mathrm{~min}$ & 85.19 & 81.27 & 80.61 & 0.044 & 0.041 & 0.865 \\
\hline $35 \mathrm{~min}$ & 83.57 & 84.43 & 84.2 & 0.769 & 0.710 & 0.809 \\
\hline $40 \mathrm{~min}$ & 79.94 & 88.12 & 89.28 & 0.031 & 0.028 & 0.589 \\
\hline $60 \mathrm{~min}$ & 81.92 & 89.76 & 88.65 & 0.019 & 0.025 & 0.878 \\
\hline
\end{tabular}

P1: between group B and A1; P2: between group B and A2, P3: between group A1 and A2

Table 3 illustrates the variation in systolic pressure in the three group over time. During the first 15 minutes after anesthesia induction group A2 showed significantly higher systolic pressure than both A1 and B groups with significant differences $(\mathrm{P}<0.05)$. Although group A1 showed higher systolic pressure than group B during the same periods, statistical analysis revealed significant differences only after 3,5 and 15 minute on induction $(\mathrm{P}<0.05)$. Comparison between group A1 and A2 showed significantly higher systolic blood pressure in A2 after 5 and 10 minutes from induction of anesthesia.

Table 3: Systolic blood pressure for the three groups over time after the induction of anesthesia

\begin{tabular}{|l|l|l|l|l|l|l|}
\hline \multirow{2}{*}{ Time } & \multicolumn{5}{|l|}{ Systolic Pressure } & P-value \\
\cline { 2 - 7 } & $\begin{array}{l}\text { Group } \\
\text { (B) }\end{array}$ & $\begin{array}{l}\text { Group } \\
\text { (A1) }\end{array}$ & $\begin{array}{l}\text { Group } \\
\text { (A2) }\end{array}$ & P1 & P2 & P3 \\
\hline Baseline & 131.28 & 127.25 & 129.42 & 0.534 & 0.511 & 0.702 \\
\hline 3 min & 109.73 & 118.19 & 120.12 & 0.029 & 0.008 & 0.654 \\
\hline 5 min & 104.32 & 109.65 & 114.34 & 0.032 & 0.021 & 0.042 \\
\hline 10 min & 108.65 & 111.29 & 116.76 & 0.048 & 0.030 & 0.045 \\
\hline 15 min & 113.59 & 121.39 & 120.17 & 0.009 & 0.019 & 0.829 \\
\hline 20 min & 119.16 & 120.13 & 118.69 & 0.376 & 0.439 & 0.432 \\
\hline 25 min & 123.29 & 124.46 & 123.08 & 0.734 & 0.834 & 0.771 \\
\hline 30 min & 123.37 & 123.9 & 125.94 & 0.922 & 0.730 & 0.684 \\
\hline 35 min & 125.7 & 124.18 & 125.12 & 0.883 & 0.876 & 0.854 \\
\hline
\end{tabular}




\begin{tabular}{|l|l|l|l|l|l|l|}
\hline $40 \mathrm{~min}$ & 124.36 & 126.32 & 124.91 & 0.645 & 0.874 & 0.545 \\
\hline $60 \mathrm{~min}$ & 123.65 & 125.43 & 123.97 & 0.342 & 0.904 & 0.756 \\
\hline
\end{tabular}

P1: between group B and A1; P2: between group B and A2, P3: between group A1 and A2

Variations in diastolic pressure between the three groups over time is shown in table 4. Both group A1 and A2 exhibited higher diastolic pressure than group $\mathrm{B}$ during the first 15 minutes with significant differences $(\mathrm{P}<0.05)$. On the other hand, at late time after anesthesia (5,20 and 30 minutes), group A1 showed significant decrease in diastolic pressure compared with group A2.

Table 4: Diastolic blood pressure for the three groups over time after the induction of anesthesia

\begin{tabular}{|c|c|c|c|c|c|c|}
\hline \multirow[t]{2}{*}{ Time } & \multicolumn{3}{|c|}{ Diastolic Pressure } & \multicolumn{3}{|c|}{ P-value } \\
\hline & $\begin{array}{l}\text { Group } \\
\text { (B) }\end{array}$ & $\begin{array}{l}\text { Group } \\
\text { (A1) }\end{array}$ & $\begin{array}{l}\text { Group } \\
\text { (A2) }\end{array}$ & $\mathrm{P} 1$ & $\mathrm{P} 2$ & P3 \\
\hline Baseline & 75.81 & 74.49 & 76.56 & 0.743 & 0.604 & 0.491 \\
\hline $3 \min$ & 62.71 & 68.35 & 70.11 & 0.033 & 0.024 & 0.091 \\
\hline $5 \min$ & 60.14 & 69.54 & 72.24 & 0.018 & 0.006 & 0.043 \\
\hline $10 \mathrm{~min}$ & 62.19 & 68.25 & 69.58 & 0.025 & 0.021 & 0.328 \\
\hline $15 \mathrm{~min}$ & 61.29 & 65.19 & 70.52 & 0.038 & 0.031 & 0.082 \\
\hline $20 \mathrm{~min}$ & 68.44 & 65.97 & 70.61 & 0.072 & 0.296 & 0.048 \\
\hline $25 \mathrm{~min}$ & 71.22 & 67.24 & 71.72 & 0.068 & 0.898 & 0.073 \\
\hline $30 \mathrm{~min}$ & 69.62 & 69.52 & 73.94 & 0.867 & 0.049 & 0.044 \\
\hline $35 \mathrm{~min}$ & 70.16 & 72.18 & 72.67 & 0.671 & 0.461 & 0.754 \\
\hline $40 \mathrm{~min}$ & 72.29 & 72.11 & 74.48 & 0.810 & 0.504 & 0.619 \\
\hline $60 \mathrm{~min}$ & 72.14 & 72.65 & 73.19 & 0.771 & 0.694 & 0.662 \\
\hline
\end{tabular}

P1: between group B and A1; P2: between group B and A2, P3: between group A1 and A2

Variation of mean blood pressures over time after the induction of anesthesia are shown in table 5. A comparison between group A2 and B shows that cases in group A2 had significantly higher mean blood pressure than group B all over the study time except at minute 35 and beyond. Group A1 showed somewhat similar trend compared with group B, but the significant differences appeared at minutes 3, 5, 15, 25 and 30. Furthermore, group A2 showed 
significantly higher mean blood pressure than group A1 at 3,10 and 15 minutes after anesthesia induction.

Table 5: mean blood pressure for the three groups over time after the induction of anesthesia

\begin{tabular}{|l|l|l|l|l|l|l|}
\hline \multirow{2}{*}{ Time } & \multicolumn{3}{|l|}{ Mean Blood Pressure } & P-value & \\
\cline { 2 - 7 } & $\begin{array}{l}\text { Group } \\
\text { (B) }\end{array}$ & $\begin{array}{l}\text { Group } \\
\text { (A1) }\end{array}$ & $\begin{array}{l}\text { Group } \\
\text { (A2) }\end{array}$ & P1 & P2 & P3 \\
\hline Baseline & 93.4 & 95.27 & 94.8 & 0.422 & 0.519 & 0.832 \\
\hline 3 min & 73.55 & 81.39 & 92.8 & 0.032 & 0.012 & 0.042 \\
\hline 5 min & 78.94 & 84.55 & 85.49 & 0.039 & 0.032 & 0.485 \\
\hline 10 min & 80.09 & 80.14 & 85.16 & 0.843 & 0.022 & 0.026 \\
\hline 15 min & 77.26 & 82.91 & 87.26 & 0.044 & 0.018 & 0.037 \\
\hline 20 min & 79.62 & 85.27 & 82.91 & 0.025 & 0.068 & 0.074 \\
\hline 25 min & 78.16 & 87.69 & 88.48 & 0.036 & 0.031 & 0.069 \\
\hline 30 min & 82.18 & 87.13 & 90.17 & 0.028 & 0.014 & 0.085 \\
\hline 35 min & 86.59 & 90.42 & 89.49 & 0.072 & 0.092 & 0.764 \\
\hline 40 min & 89.92 & 92.18 & 92.21 & 0.756 & 0.734 & 0.956 \\
\hline 60 min & 88.25 & 92.76 & 92.54 & 0.865 & 0.884 & 0.993 \\
\hline
\end{tabular}

P1: between group B and A1; P2: between group B and A2, P3: between group A1 and A2

The number (and percentage) of cases experienced hypotension in the three groups are shown in table 5. During the first 20 minutes after anesthesia induction, 18 women (60\%) experienced hypotension compared to 11(36.67\%) in group A1 and only 6 (20\%) in group A2 with highly significant difference between group A2 and B $(\mathrm{P}<0.001)$. During the time period between 20 and 40 minutes, the three group exhibited close numbers of cases that had hypotension, and there were no significant differences. Totally, group had higher number of women (21 cases) having hypotension than group A2 (7 cases) with highly significant difference $(\mathrm{P}<0.001)$, however, the difference between group $\mathrm{B}$ and A1 was non-significance $(\mathrm{P}=0.057)$. 
Table 6: Frequency of hypotension in the three groups

\begin{tabular}{|c|c|c|c|c|}
\hline Hypotension & $\begin{array}{l}\text { Direct lying } \\
\text { (30 cases) }\end{array}$ & $\begin{array}{l}\text { After } 1 \text { minute } \\
\text { ( } 30 \text { cases) }\end{array}$ & $\begin{array}{lr}\begin{array}{l}\text { After } \\
\text { minutes }\end{array} & \mathbf{2} \\
\text { cases }) & \end{array}$ & P-value \\
\hline Induction- $20 \mathrm{~min}$ & $18(60 \%)$ & $11(36.67 \%)$ & $6(20 \%)$ & $\begin{array}{l}\mathrm{P} 1=0.06 \\
\mathrm{P} 2<0.001 \\
\mathrm{P} 3=0.077\end{array}$ \\
\hline $20-40$ min & $3(10 \%)$ & $3(10 \%)$ & $1(3.33 \%)$ & $\begin{array}{l}\mathrm{P} 1=1.0 \\
\mathrm{P} 2=0.29 \\
\mathrm{P} 3=0.29\end{array}$ \\
\hline Total & $21(70 \%)$ & $14(46.67 \%)$ & $7(23.33 \%)$ & $\begin{array}{l}\mathrm{P} 1=0.065 \\
\mathrm{P} 2<0.001 \\
\mathrm{P} 3=0.056\end{array}$ \\
\hline
\end{tabular}

P1: between first and second group, P2: between first and third group, P3: between second and third group

Mean ephedrine requirements in direct lying, after 1 minute lying and after 2 minutes lying was $14.8 \pm 4.5 \mathrm{mg}, 13.4 \pm 3.9 \mathrm{mg}$ and $9.3 \pm 3.8 \mathrm{mg}$ respectively with significant differences between groups $(\mathrm{P} 1=0.192$ between group $\mathrm{B}$ and $\mathrm{A} 1 ; \mathrm{P} 2=0.006$ between group $\mathrm{B}$ and $\mathrm{A} 2$; and $\mathrm{P} 3=0.012$ between group A1 and A2) as shown in table 6.

Table 7: ephedrine requirement in the different groups

\begin{tabular}{|l|l|lr|lr|l|}
\hline Groups & $\begin{array}{l}\text { Direct lying } \\
\text { (30 cases) }\end{array}$ & $\begin{array}{l}\text { After } \\
\text { minute } \\
\text { cases })\end{array}$ & $\begin{array}{r}\mathbf{1} \\
\mathbf{3 0}\end{array}$ & $\begin{array}{l}\text { After } \\
\text { minutes } \\
\text { cases })\end{array}$ & $\begin{array}{r}\mathbf{2} \\
\mathbf{3 0}\end{array}$ & P- value \\
\hline $\begin{array}{l}\text { Ephedrine } \\
\text { requirements, } \\
\text { mg (mean } \pm \text { SD) }\end{array}$ & $14.8 \pm 4.5$ & $13.4 \pm 3.9$ & $9.3 \pm 3.8$ & $\begin{array}{l}\mathrm{P} 1=0.192 \\
\mathrm{P} 2=0.006 \\
\mathrm{P} 3=0.012\end{array}$ \\
\hline
\end{tabular}

P1: between first and second group, P2: between first and third group, P3: between second and third group, SD: standard deviation

Table 7 show the time required to reach T6 dermatome sensory level in the three groups. Group A2 exhibited longer time period to reach this level $(4.73 \pm 1.69 \mathrm{~min})$ than both Group A1 $(3.77 \pm 2.1 \mathrm{~min})$ and group B $(3.25 \pm 1.1$ min) with significant difference from group $B(P=0.026)$. 
Table 8: the time required to reach T6 dermatome sensory level in the different groups

\begin{tabular}{|c|c|c|c|c|}
\hline Groups & $\begin{array}{l}\text { Direct lying } \\
\text { (30 cases) }\end{array}$ & \begin{tabular}{|lr}
$\begin{array}{l}\text { After } \\
\text { minute }\end{array}$ & 1 \\
cases) & $(30$ \\
\end{tabular} & $\begin{array}{lr}\begin{array}{l}\text { After } \\
\text { minutes }\end{array} & 2 \\
\text { cases) } & (30 \\
\end{array}$ & P-value \\
\hline $\begin{array}{l}\text { Time required } \\
\text { to reach T6 } \\
\text { sensory level, } \\
\text { min (mean } \pm \text { SD) }\end{array}$ & $4.83 \pm 1.69$ & $3.77 \pm 2.1$ & $3.25 \pm 1.1$ & $\begin{array}{l}\mathrm{P} 1=0.037 \\
\mathrm{P} 2=0.029 \\
\mathrm{P} 3=0.293\end{array}$ \\
\hline
\end{tabular}

P1: between first and second group, P2: between first and third group, P3: between second and third group, SD: standard deviation

\section{Table 9: Apgar score in 3 groups}

\begin{tabular}{|c|c|c|c|c|c|c|c|c|c|c|c|c|}
\hline Apgar score & 1 & 2 & 3 & 4 & 5 & 6 & 7 & 8 & 9 & 10 & Total & p \\
\hline A1-1mint & 0 & 0 & 0 & 0 & 0 & 0 & 0 & 7 & 23 & 0 & 30 & \multirow{6}{*}{0.00} \\
\hline A1-5mint & 0 & 0 & 0 & 0 & 0 & 0 & 0 & 0 & 16 & 14 & 30 & \\
\hline A2-1mint & 0 & 0 & 0 & 0 & 0 & 0 & 0 & 0 & 17 & 13 & 30 & \\
\hline A2-5mint & 0 & 0 & 0 & 0 & 0 & 0 & 0 & 7 & 23 & 0 & 30 & \\
\hline B-1mint & 0 & 0 & 0 & 0 & 0 & 0 & 0 & 0 & 26 & 4 & 30 & \\
\hline \multirow[t]{2}{*}{ B-5mint } & 0 & 0 & 0 & 0 & 0 & 0 & 0 & 20 & 10 & 0 & 30 & \\
\hline & \multicolumn{6}{|c|}{ Poor } & Accepted & \multicolumn{3}{|c|}{ Normal } & & \\
\hline
\end{tabular}

Chi-square=103.500; $\mathrm{DF}=10 ; \mathrm{P}$-Value $=0.000$

6 cells with expected counts less than 5

We found that Apgar score $>8$ in all groups.

\section{Discussion}

Hypotension following spinal anesthesia is very common, and a recent meta-analysis showed that the following Treatments are not completely successful in eliminating this adverse event: position changes, colloids, ephedrine, Phenylephrine, or lower legs compression ${ }^{(6)}$. In a number of studies, the effect of patient positioning during or after spinal anesthesia has been studied, although Conflicting results have been reported ${ }^{(7-10)}$. Investigators have shown better hemodynamics and reduced ephedrine requirements when the spinal anesthetic was performed in the sitting rather than in the lateral position. $(11,12)$ 
In 2011, El-Hakeem et al., found that sitting up for 5 minutes rather than immediately lying down resulted in decreased sensory block Height, reduced ephedrine and fluid requirements, and diminished some adverse effects such as nausea and vomiting ${ }^{(7)}$

Pooran hajian et al., ${ }^{(13)}$ found keeping the paturiant seated for 1 and 2 minutes after spinal anesthesia , compared to immediately lying down, could decrease the frequency of hypotension and ephedrine use.

Kohler et al., ${ }^{(14)}$ and Gori et al., ${ }^{(15)}$ in similar studies Found that sitting up for 3 and 2 minutes, respectively Did not influence the incidence of maternal hypotension Or the required ephedrine dose versus immediately lying down, as well as B.l Obasuyi et al., found Hypotension occurred less frequently when spinal anaesthesia for caesarean using plain bupivacaine was induced with patients in the lateral compared with the sitting position. ${ }^{(16)}$

Conclusions: This study revealed that the patient's position is an important factor, which affects the frequency of Hypotension and the onset of sensory block, as well as Administration of spinal anesthesia for cesarean section. Based on the findings, keeping the parturient seated for 1 Or 2 minutes after spinal anesthesia, compared to immediately lying down, could decrease the frequency of hypotension.

\section{References}

1. "Fear a factor in surgical births". The Sydney Morning Herald. 7 October 2007.

2. "Kiwi caesarean rate continues to rise". Stuff.co.nz. 12 September 2007. Retrieved22 September 2011.

3. Finger C (2003). "Caesarean section rates skyrocket in Brazil. Many women are opting for Caesareans in the belief that it is a practical 
solution". Lancet 362 (9384): 628.doi:10.1016/S0140-6736(03) 142 04-3. PMID 12947949

4. Miller R (ed.). In: [Bsics of Anesthesia], 6th ed. Churchill Living stone, 2011

5. Morgan and Mikhails clinical Anesthesiology.John F,Buttrer, Worth,David C,Mackey,John D,Wasnick.2013:5 ${ }^{\text {th }}$ edition obstetric Anesthesia;p 855 Anna Lee, Warwick D.Ngan Kee, Tony Gin.Prophylactic Ephedrine prevents hypotension during spinal anesthesia for cesarean delivery but doesnot improve neonatal outcome:a quantitative systemic review.Can $\mathbf{J}$ Anaesth2002 Jun-Jul;49(6);588-99.

6. Cyna AM, Andrew M, Emmett RS, Middleton P, Simmons SW.Techniques for preventing hypotension during spinal anaesthesia for caesarean section. Cochrane Database Syst Rev 2006; 4: CD002251.

7. El-Hakeem EE, Kaki AM, Almazrooa AA, Al-MansouriNM,Alhashemi JA. Effects of sitting up for five minutes versus immediately lying down after spinal anesthesia for Cesarean delivery on fluid and ephedrine requirement; a randomized trial. Can J Anaesth. 2011;58(12):1083-9. doi: 10.1007/s12630-011-9593-4. [PubMed: 21971743].

8. Chevuri SB, Rao JVS, Chandergutti V, Hussain MM, Khan BA. A Comparative Study of Effects of Sitting and Lateral Positions on Quality of Block during Induction of Spinal Anaesthesia in Patients Undergoing Cesarean Section. J Cont Med A Dent. 2015;3(1).

9. Ortiz-Gomez JR, Palacio-Abizanda FJ, Morillas-Ramirez F, Fornet-Ruiz I, Lorenzo-Jimenez AM, Bermejo-Albares ML. Effect of position on maternal haemodynamics during elective caesarean delivery under spinal anaesthesia. Anaesthesia. 2015;5:7. 
10. Obasuyi BI, Fyneface-Ogan S, Mato CN. A comparison of the haemodynamic effects of lateral and sitting positions during induction of spinal anaesthesia for caesarean section. Int $J$ Obstet Anesth. 2013;22(2):124-8. doi: 10.1016/j.ijoa.2012.12.005. [PubMed: 23453465].

11.Patel M, Samsoon G, Swami A, Morgan B. Posture and the spread of hyperbaric bupivacaine in parturients using the combined spinal epidural technique. Can J Anaesth 1993; 40: 943-6.

12.Inglis A, Daniel M, McGrady E. Maternal position during induction of spinal anaesthesia for caesarean section. A comparison of right lateral and sitting positions. Anaesthesia 1995;50: 363-5.

13.Hajian P, Nikooseresht M, Lotfi T. Comparison of 1- and 2-Minute Sitting Positions Versus Immediately Lying Down on Hemodynamic Variables After Spinal Anesthesia with Hyperbaric Bupivacaine in Elective Cesarean Section. Anesthesiology and Pain Medicine. 2017;7(2):e43462. doi:10.5812/aapm.43462.

14.Kohler F, Sorensen JF, Helbo-Hansen HS. Effect of delayed supine positioning after induction of spinal anaesthesia for caesarean section. Acta Anaesthesiol Scand. 2002;46(4):441-6. [PubMed: 11952447].

15.Gori F, Corradetti F, Cerotto V, Peduto VA. Influence of positioning on plain levobupivacaine spinal anesthesia in cesarean section. Anesthesiol Res Pract. 2010;2010 doi: 10.1155/2010/212696. [PubMed:20700432].

16. Obasuyi BI, Fyneface-Ogan S, Mato CN. A comparison of the haemodynamic effects of lateral and sitting positions during induction of spinal anaesthesia for caesarean section. Int J Obstet Anesth. 2013 Apr;22(2):124-8. 